\title{
HVMANITAS
}

\section{A 'cloud of Metaphysics' in Pindar: the opening of Nemean 6}

Autor(es): $\quad$ Frederico, Lourenço

Publicado por: Faculdade de Letras da Universidade de Coimbra, Instituto de Estudos

URL

persistente: URI:http://hdl.handle.net/10316.2/22913

DOI: $\quad$ DOI:http://dx.doi.org/10.14195/2183-1718_63_2

Accessed : $\quad$ 26-Apr-2023 14:23:26

A navegação consulta e descarregamento dos títulos inseridos nas Bibliotecas Digitais UC Digitalis, UC Pombalina e UC Impactum, pressupõem a aceitação plena e sem reservas dos Termos e Condições de Uso destas Bibliotecas Digitais, disponíveis em https://digitalis.uc.pt/pt-pt/termos.

Conforme exposto nos referidos Termos e Condições de Uso, o descarregamento de títulos de acesso restrito requer uma licença válida de autorização devendo o utilizador aceder ao(s) documento(s) a partir de um endereço de IP da instituição detentora da supramencionada licença.

Ao utilizador é apenas permitido o descarregamento para uso pessoal, pelo que o emprego do(s) título(s) descarregado(s) para outro fim, designadamente comercial, carece de autorização do respetivo autor ou editor da obra.

Na medida em que todas as obras da UC Digitalis se encontram protegidas pelo Código do Direito de Autor e Direitos Conexos e demais legislação aplicável, toda a cópia, parcial ou total, deste documento, nos casos em que é legalmente admitida, deverá conter ou fazer-se acompanhar por este aviso. 
humanitas

Vol. LXIII

2011 


\title{
A 'CLOUD OF METAPHYSICS' IN PINDAR: THE OPENING OF NEMEAN 6
}

\author{
Frederico Lourenço \\ FLUC - $\mathrm{CECH}$
}

\begin{abstract}
Resumo
O presente artigo põe em causa algumas abordagens tradicionais às $\gamma v \hat{\omega} \mu \alpha \iota$ de Píndaro e revê o problema na interpretação das palavras iniciais da Nemeia VI, posicionando-se do lado daqueles que, ao contrário da actual tradução da série Loeb, entendem que a afirmação inicial de Píndaro é no sentido de sublinhar que deuses e homens pertencem à mesma raça.
\end{abstract}

Palavras-chave: Píndaro, enunciados gnómicos, odes nemeias.

\begin{abstract}
This article questions traditional approaches to Pindar's $\gamma v \hat{\omega} \mu \alpha \iota$ and reviews the problem in interpreting the opening words of Nemean 6, coming down on the side of previous interpretations which, unlike the current Loeb translation, see Pindar as saying that gods and men belong to the same race.
\end{abstract}

Key-words: Pindar, gnomic utterance, Nemean odes.

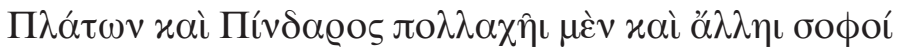
Plato and Pindar in various different respects are ooфoí

Aelius Aristides, Oration 34.5 


\section{How (not) to read Pindar}

How best to read Pindar has been an on-going problem since the editio princeps was published in Venice in the early Sixteenth Century (1513), followed two decades later by the first Latin translation (1535). Poets in particular, from Ronsard to Tennyson and Ezra Pound ${ }^{1}$, have been perplexed down the centuries, although interestingly enough German poets have tended to read Pindar differently from their French and English counterparts: Hölderlin not only translated but successfully imitated Pindar; Goethe and many others proved sympathetic readers. This is probably one of the reasons why, from the Nineteenth Century to the present day, German speaking classical scholars approach Pindar in a way that is significantly different from the way Pindar is most often read in Anglophone universities. For Hugo Jurenka, writing on Nemean 6 in 1899, it was perfectly natural to read the opening strophe as philosophy - perhaps not very surprising if we think that two of Nietzsche's main books (Die fröhliche Wissenschaft and Ecce Homo) take as their explicit philosophical starting point a Pindaric

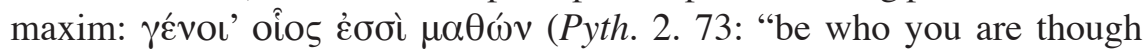
learning" $)^{2}$. In recent years, we have seen at least two important books in German written by philosophers taking Pindar seriously as a "philosopher", that is to say that the many maxims and $\gamma v \hat{\mu} \mu \alpha$ that abound in Pindar's poems are taken as actually having philosophical value ${ }^{3}$. This approach is radically different from the typical Anglo-Saxon dismissal of these maxims as "uniformly trite and obvious".

As is well known, something of a revolution in Pindaric studies occurred in the early Sixties of the last century, when the American scholar Elroy Bundy published "agenda shaping" 5 essays on two odes of Pindar. Bundy's concern was to show that Pindar is essentially a professional poet working within the conventions of the different genres he cultivated. The Pindaric ode (such as we know it for the most part) is an غ̇ंıvíxıov, a song composed to celebrate an athletic victory in the Olympian, Pythian, Nemean or Isthmic Games. This type of poem was a professional commission for

${ }^{1}$ References in Burnett 2005: 3.

${ }^{2}$ See Hollingdale ${ }^{2}$ 2001: 37.

${ }^{3}$ Theunissen 2000; Janke 2005.

${ }^{4}$ Norwood 1945: 69. Cf. also Burton's dismissal of the closing reflections in Pythian 12 as "trite maxims" (Burton 1962: 26).

${ }^{5}$ Currie 2005: 11. 
which the poet received payment, so the tone would on the face of it appear more likely to be impersonal rather than personal, all the more so since ostensibly the ode was meant to be performed by a chorus. But "impersonal" is the last word that would occur to anyone in describing Pindar's poetry. The odes are full of subjective statements in the first person singular; and this is so much a part of the tapestry of the Pindaric poem that already Wilamowitz suggested in 1922 that some of Pindar's odes may not have been meant for choral performance, but for solo performance ${ }^{6}$. This idea was taken further by Mary Lefkowitz and Malcolm Heath, who argued more widely for solo performance, a view that was met with scepticism by some scholars - or with modified scepticism by others, including myself f $^{7}$.

However, this is not the place to revisit the question of performance, since my main concern here is with meaning; but I will revisit some of Bundy's statements about Pindar, not so much to add to the many scholarly controversies attempting refutation or endorsement of Bundy, but simply because Bundy conveniently sets out problems in reading Pindar which I propose to view from the opposite end of the spectrum. Bundy writes at the end of Studia Pindarica: "in the determination of sense and effect as they subserve the harmony of the whole, convention rules. Language which admits, on the assumption of its uniqueness, a wide variety of interpretations, becomes, when the conventional elements have been isolated and identified, unambiguous, or ambiguous only in a controlled sense. If my analysis is correct, it seems apparent that in this genre the choice involved in composition is mainly a choice of formulae, motives, themes, topics, and set sequences of these that have, by convention, meanings not always easily perceived from the surface denotations of the words themselves. [...] The study of Pindar must become a study of genre. No longer can we view the odes as the production of an errant genius..."

My view is that great poetry - and it would be idle to waste any time "proving" the obvious by explaining why Pindar is great poetry - great poetry, then, is by its very nature inimical to the concept of unambiguous language or language that is allowed only a controlled form of ambiguity. "Nel mezzo del cammin di nostra vita" (Dante), "Much have I travelled in realms of gold" (Keats), "Atmen, du unsichtbares Gesicht" (Rilke), "Uma

\footnotetext{
${ }^{6}$ Wilamowitz 1922: 240.

${ }^{7}$ Cf. Lourenço 2009: 19-29.

${ }^{8}$ Bundy 1986: 91-92.
} 
ternura confusa, como um vidro embaciado, azulada" (Pessoa): in any great poetry of any age, giving ambiguity full reign is of the essence. As we shall see, the fact that traditional language is an ingredient of Pindaric language does not detract from its uniqueness: traditional expressions taken from Homer or Hesiod often reinforce the sense of ambiguity and the possibility of richly complex and multifarious readings of the same poetic words. To describe the Pindaric process of composition as mainly a choice of formulae and set sequences invites the question: why isn't Pindar more like Bacchylides? Surely, something must account for the difference.

Furthermore, Bundy's view that everything in the Pindaric victory ode is primarily encomiastic seems to me grossly exaggerated: it is necessary to read the poems against the text to say that all the different ingredients in the ode, including mythical narrative and "personal" statements, have one function alone: to praise the victor. The "philosophical" $\gamma v \omega \hat{\mu} \alpha$, in particular, are hard to fit in with this view. Tellingly, the best thing that Bundy can say about them is that they provide "foil" or contrast - a term annoyingly overused in Studia Pindarica, although it should be said that he was not its $\pi \varrho \omega ̂ \tau o \varsigma ~ \varepsilon \dot{v} \varrho \tau \eta \dot{\zeta s, ~ a s ~ R o g e r ~ D a w e ~ o n c e ~ p o i n t e d ~ o u t: ~}$ "the name of a recent Californian critic is on the lips of all for seeing Pindar in terms of one constantly setting things in relief against each other, and he has made the term 'foil' a current term of criticism. Turn to the commentary on Pindar by Gildersleeve, published in 1885, and on the first page you will find the bare statement "much in Pindar is merely foil'. 9"'

For Bundy, then, Pindar's $\gamma v \omega \hat{\mu} \mu \alpha$ are relevant as structure, because of their use in effecting or smoothing the transitions between different sections in the poem, but he never admits that they may be relevant as content. The closest he comes to expressing a positive view on Pindar's use of $\gamma v \hat{\mu} \mu$ a is this: "gnomic foil, whether it precedes or follows its focal point, provides by analogy or contrast a category appropriate to the point of interest which it glosses" (p. 81).

Why, according to Bundy, is there no philosophical content in Pindar's $\gamma v \omega \mu \alpha \iota$ ? Because "we forget that this is an oral, public, epideictic literature dedicated to the single purpose [my emphasis] of eulogizing men and communities... that the environment thus created is hostile to an allusiveness that would strain the powers of a listening audience, hostile

${ }^{9}$ Dawe 1993: 15. 
to personal, religious, political, philosophical, and historical references that might interest the poet but do nothing to enhance the glory of a given patron" (p. 35). One might ask whether Greek tragedy was not also an equally "oral, public, epideictic literature" and whether that prevented the tragedians from including religious, political, philosophical and historical references?

That French and German classical scholarship ${ }^{10}$ was less that enchanted with Bundy's approach need hardly be stressed. But in AngloSaxon circles reception of Bundy has been mainly positive and, even today, many eminent scholars who produce otherwise valuable work in English on Pindar are still writing under Bundy's spell ${ }^{11}$. In the words of P. W. Rose, "it would be all but impossible to overestimate the impact of Bundy's work on the way we all read Pindar"12. Fortunately, the word "all" here is relative...

Be that as it may, perhaps my main objection to Bundy's view of Pindar as a businessman-poet professionally dealing in genre and convention is that it is contrary to how Pindar himself presents his creative identity, or (to quote the title of Maehler's famous book) contrary to Pindar's own Auffassung of his Dichterberuf ${ }^{13}$. How would Pindar have preferred to be described? Here the title of another famous book springs to mind: Jacqueline Duchemin's Pindare, Poète et Prophète (Paris, 1955). The expression "poète et prophète" probably sounds a little far-fetched in 2011, but we would be wrong to think that "prophète" is less apposite than "poète" in describing Pindar: for the fact remains that Pindar actually does

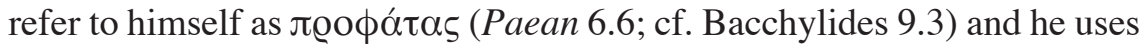

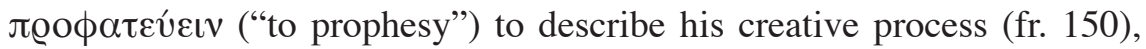

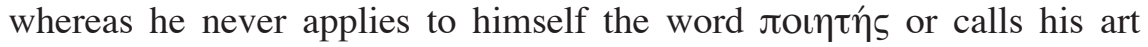

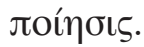

\section{Pindar бoфós}

Pindar prefers to describe himself as бoфós and regularly uses the word бoфí $\alpha$ to describe his art, as did Solon and Xenophanes before him.

${ }^{10}$ With the notable exception, as regards German scholarship, of Erich Thummer.

${ }^{11}$ See for instance Race 2004: 69-96.

${ }^{12}$ Rose 1992: 154.

${ }^{13}$ Maehler 1963. 
Whether or not we are entitled to apply to Pindar the same definition of бoфía that Bowra uses of Xenophanes ("his own blend of philosophy and poetry") depends, of course, on what we mean by "philosophy" and whether the very term itself is not an anachronism as applied to Xenophanes - and thus even more so to Pindar. In true German fashion, Werner Jaeger did not hesitate to speak of "eine ganze Philosophie... voll tiefer Besinnung" with reference to Pindar ${ }^{14}$; and more recently Michael Theunissen's monumental thousand-page book Pindar: Menschenlos und Wende der Zeit (2000; ${ }^{2} 2002$ ) points in the same direction.

For my part, I would suggest that Theunissen's description of Pindar as a "poet-thinker" (Dichterdenker: p. 7) is a definite improvement on the "trite and obvious" tag applied to Pindar's deeper utterances and that, accordingly, there is something rewarding to be gained in assuming that бoфí $\alpha$ in Pindar is, as Bowra said of Xenophanes, a blend of poetry and philosophy. That being the case, in what sense could we meaningfully understand "philosophy"? Clearly not in the sense that we term the poetry of Parmenides "philosophy", much less in the sense that we so term the works of Plato, because what both of them set out to write was, however differently, not a blend of "philosophy and something else" but primarily philosophy (despite the fact that Parmenides wrote in Homeric verse and Plato in uniquely expressive prose). Pindar, it will have to be conceded, obviously does not address philosophical questions as such; but it is my view that his lyric reflections on Time, Destiny, Divinity, etc. do purport to make sense of the human condition in what one might call a loosely "philosophical" way. Certainly philosophers ancient and modern have found that Pindar said relevant things on this important subject (Plato and Schopenhauer both quote him on "life"15); and this prompts the suggestion that, if we are to define the "philosophic" half of Pindaric бoфí $\alpha$, perhaps the most suitable heading might be "philosophy" taken (long before Kierkegaard or Nietzsche!) as some Archaic Greek form of "existentialism" - the most readily available definition of which (Wikipedia, no less) fits Pindaric ooфía like a glove: a philosophy focussed "on the condition of human existence, and an individual's emotions, actions, responsibilities and thoughts, and the meaning or purpose of life."

${ }^{14}$ Jaeger 1934: 284.

${ }^{15}$ Cf. Arthur Schopenhauer, Die Welt als Wille und Vorstellung, Book I, $§ 7$. 


\section{Gods and Men}

With all this in mind, we now turn to the opening strophe of the Sixth Nemean Ode (1-7):

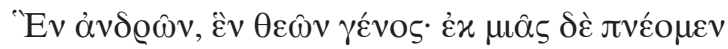

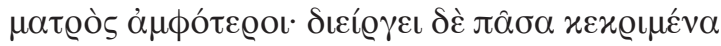

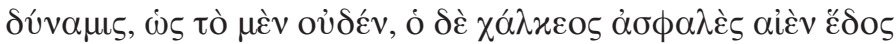

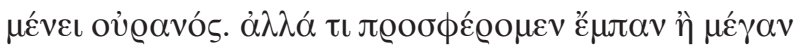

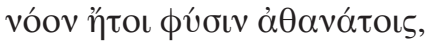

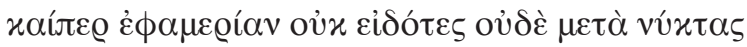

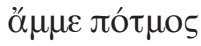

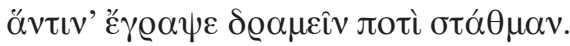
There is but one race of god and men. From one mother we both draw breath. But a wholly distinct power separates us, for one race is nothing, whereas the bronze sky remains forever an unshakeable abode. But we do resemble the immortals in some way, either in greatness of mind or in our nature, although neither by day nor at night do we know the course that destiny has written for us to run.

This beautiful strophe is justly famous, for, as Wilamowitz wrote in 1922, Pindar never expressed anything deeper than this ("tieferes hat Pindar nie gesagt") ${ }^{16}$. More recently (2005), Anne Burnett attractively labelled this stanza a "cloud of metaphysics", although she did not see fit to explain why ${ }^{17}$. Clouds and metaphysics apart, what these lines do is to plunge us straight into the ambiguity problem referred to above, because they have been read since the Nineteenth Century in two completely different ways. Is Pindar saying that there is only one race of gods and men - or is he saying that there are two races, one of men, another of gods?

Perhaps I should mention at this point is that, although I follow William Race's useful edition of Pindar in the Loeb Library (more up to date than Snell's Teubner text and with corrected line-numbers), I do not follow his English translation, because in the controversy in determining the meaning of the opening statement, Race sides with Bundy (p. 37) and

\footnotetext{
${ }^{16}$ Wilamowitz 1922: 398.

${ }^{17}$ Burnett 2005: 159.
} 
others, who think Pindar is saying "there is one race of men, another of gods". Bundy's argument rests on what I wish to name a structural fallacy. His view of the so-called "priamel" form requires terms contrasted by "foil" to be climactically grouped in a single category. Never mind what the words actually say. So, to quote Bundy, "gods and men are the terms included in the foil, and are presented as separate and distinct categories". In a footnote to this statement he adds: "the proof that $\check{\varepsilon} v . . . \check{\varepsilon} v$ (= $\varepsilon$ $\tau \varepsilon \varrho o v . .$.

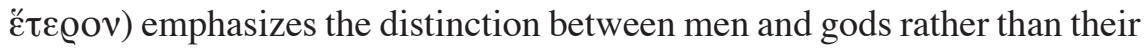
common origin is in the priamel form". One might prefer to think that the proof lies in Pindar's Greek, which in fact says exactly the opposite.

I therefore follow Fennell (1899), Jurenka (1899), Bowra (1964), Hermann Fränkel (1962) and our own conimbricenses, Professors Rocha Pereira and Ribeiro Ferreira, with regard to this question. As Bowra wrote, "it should not be necessary to point out that the second $\check{\varepsilon} v$ cannot mean

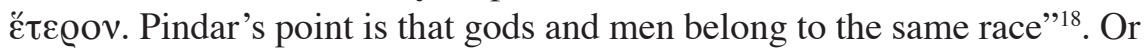
again, in Fränkel's interpretation, "eine und diesselbe ist der Menschen und Götter Herkunft"19. Professor Rocha Pereira translates "uma só é a raça dos homens e dos deuses" (Hélade), as does Professor Ribeiro Ferreira "Uma, uma só a raça dos humens e dos deuses"20.

The fact that the numeral one appears three times in the first seven words of the poem obviously reinforces the idea of unity, rather than the reverse. Moreover, as every Hellenist knows, there is a grammatical problem in defending any interpretation other than "one and the same": if Pindar were saying that gods and men belong to different races, we would

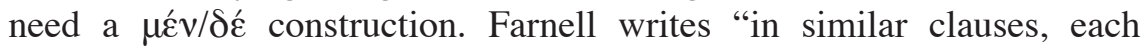
introduced by $\check{v} v$, diversity is intended, but always with $\mu \varepsilon \dot{v} v$ and $\delta \varepsilon^{\prime \prime 2}$. Peter von Kloch-Kornitz attempted to refute this grammatical argument with the objection that Pindar was too "willful" (eigenwillig) a user of the Greek language for one to expect normal Greek usage ${ }^{22}$, but that entails reading the text not as it was written, but as it might have been written, had the poet written words which in fact he did not write... a Pandora's box we would be wise not to open.

\footnotetext{
${ }^{18}$ Bowra 1964: 96.

${ }^{19}$ Fränkel 1962: 539.

${ }^{20}$ J. Ribeiro Ferreira in Lourenço (org.) 2006: 168.

${ }^{21}$ Farnell 1965: 282.

${ }^{22}$ Kloch-Kornitz 1961: 370-371.
} 
Having settled, then, the linguistic problem and concluded that Pindar was saying that gods and men are but one race, we find ourselves caught up in an apparent refutation of Homeric "anthropology". There is so much Homer in Pindar that departures from the accepted Homeric worldview must somehow appear to us deliberate and significant. Book 5 of the Iliad is especially relevant here. Apollo repels the attack of the warrior Diomedes, who, by fighting the gods, is more than overstepping his human condition. The poet says that after Diomedes had hurled himself against Apollo for

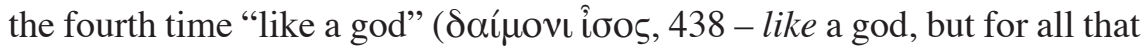
not a god), Apollo gave a terrible cry and said (440-442):

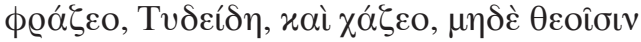

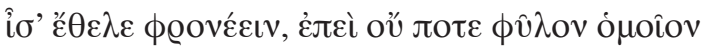

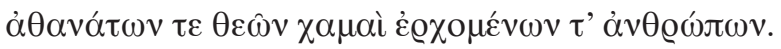
Consider, son of Tydeus, and yield! Do not seek
to think the same as the gods, for the race of immortal gods
is not the same as that of men who walk the earth.

The idea that gods and men do not share the same nature had been presented earlier in Book 5, in the episode where Diomedes wounds

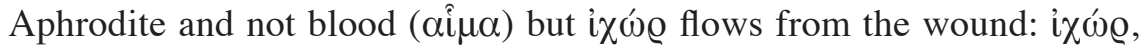

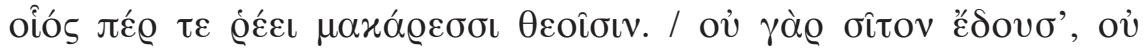

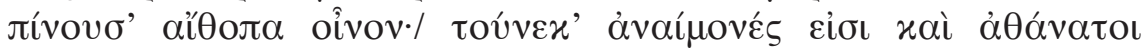

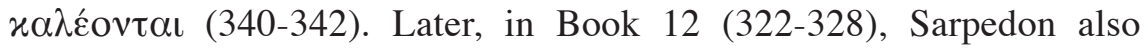
stresses the difference between men and gods and the impossibility of mortals becoming immortal. Significantly, he is himself a son of Zeus, but not even he - any more than Achilles, son of Thetis - can escape the

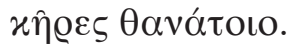

Pindar, then, while using traditional Epic language (cf. Od. $6.42 \theta \varepsilon \omega \hat{v}$

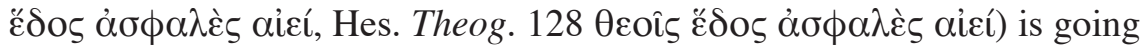
against Homeric tradition and following an alternative line - one which we

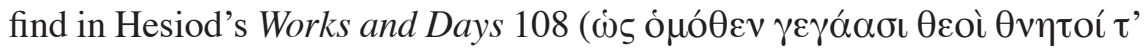
óv $\theta \varrho \omega \pi \mathrm{o})$ and later in Plato's Protagoras, where it is said that man is the

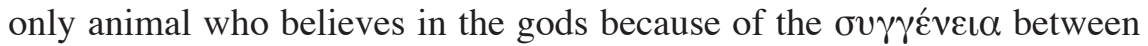
gods and men (Prt. 322a3). Some measure of the originality of Pindar's idea that gods and men have the same origin can be gaged from the simple fact that both passages, the Hesiodic and the Platonic, have fallen under suspicion as spurious later additions to the text and are accordingly printed 
enclosed by square brackets in the Budé editions of both authors (not in the Oxford editions, however).

Let us now look a little closer at Pindar's contention that gods and men are but one race (that is, both descend from Gaia, the Earth). Despite their obvious differences - human beings described as oủdév (nothing) certainly makes them most ungodlike - they do share important things in common: no

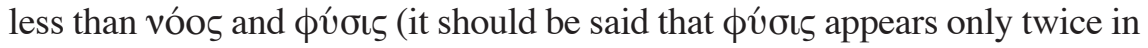
the extant Pindaric corpus: here and at Isth. 4. 49; whereas we find vóos

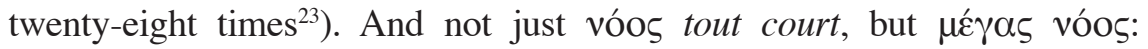
"greatness of mind"; again a Hesiodic expression (Theog. 37), but one which Hesiod applied only to Zeus. It is seems very bold of Pindar to claim that

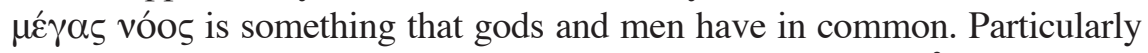

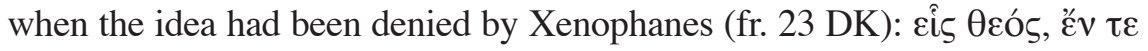

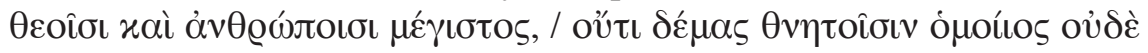
vó $\mu \alpha$. Was Pindar deliberately attempting to refute Xenophanes? That, at any rate, was the view of Hugo Jurenka in $1899^{24}$. Even though his idea was first forgotten, then unearthed a hundred years later only to be rejected by Douglas Gerber ${ }^{25}$, I think it still merits serious attention.

As for the rare Pindaric word фúoıs, it brings us back to Homer and to Sarpedon's words to the effect that it is not in our nature as humans to become ageless and immortal: therefore it is impossible for ßootoí to become gods. But what Pindar is most probably saying at the beginning of Nemean 6 is again anti-Iliadic in content: what he seems to me to be suggesting is that it is not outside the nature of human púoıs to become deathless and immortal (I will substantiate this presently). Here we are

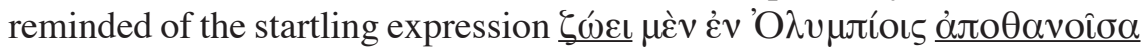
applied to Semele in Olympian 2 (25), or the lines in the same poem that describe Ino's change of condition, from mortal woman to immortal sea-

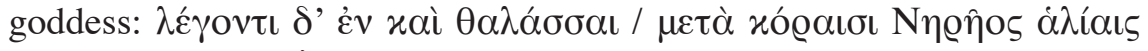

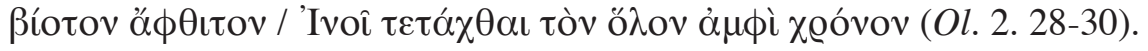
The Pindaric worldview, unlike the Iliadic, does admit in a special sense the possibility of mortals becoming immortal, as we shall see below.

(I open a brief parenthesis to explain why I am differentiating "Iliadic" from "Homeric". The reason for this is that a case can be made for a diffe-

\footnotetext{
${ }^{23}$ A list of occurences is provided by Sullivan 1990: 199-201.

${ }^{24}$ Jurenka 1899: 348-361.

${ }^{25}$ Gerber 1999: 47.
} 
rent attitude to mortals becoming immortal in the Odyssey. As we know, in Book 5 Calypso offers to make Odysseus immortal, the implication being that such a change would have been possible had he so wished (Od. 5. 1356 ; 209). That such a change is not impossible in the Odyssean poet's worldview is proven later on in the same Book 5: Odysseus out at sea and on the verge of drowning actually encounters a being who did undergo that "metaphysical" change, none other than the afore-mentioned Ino herself (Od. 5. 333-335). It will also be remembered that earlier, in Book 4, Menelaus had been told that he would be granted the exceptional grace of avoiding death completely: instead of dying, he could expect to be wafted

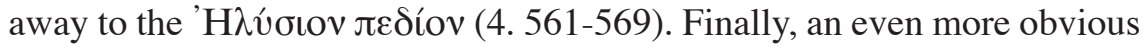
difference between Iliadic and Odyssean views of (im)mortality is provided by Helen's brothers, the Dioscuroi. In the Iliad they clearly died and were buried (Il. 3. 243-244), but in the Odyssey they are immortal on alternate days (Od. 11. 301-304) - exactly as in Pindar's Tenth Nemean Ode.)

So, to sum up, what Pindar is telling us about the similarity between gods and men is the following: (1) we belong to the same race and descend from the same mother; (2) we resemble each other with regard to vóos and

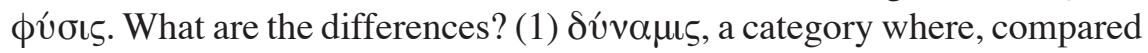
to the gods, human beings are as "nothing" (oủ $\delta$ ćv); and (2) ignorance of the future. Oứćv reminds us of the expression Sophocles will use later,

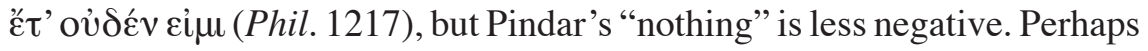
more like Fernando Pessoa's "nothing" at the beginning of his poem "Tabacaria": "Não sou nada. / Nunca serei nada. / Não posso querer ser nada. / À parte isso, tenho em mim todos os sonhos do mundo".

Most importantly, Pindar does not explicitly say that the difference between men and gods is that we as mortals have to die, whereas the gods live forever. The conceptual opposition is not mortal/immortal. The reason for this, as we read later on in the same poem, is that immortality, or a form of immortality, is possible for some men: not surprisingly, immortality

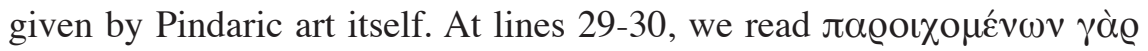

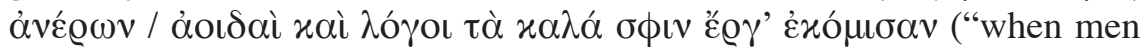
are dead and gone, songs and words preserve for them their noble deeds"). This idea is often repeated in the Pindaric corpus, notably in Pythian 3, a poem about the rights and wrongs of attempting to make mortals immortal (Asclepius is punished by Zeus for raising a dead man), but which ends

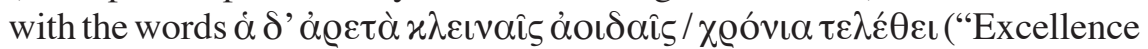
endures in glorious songs for a long time", Pyth. 3. 114-115). The ooфós 
cannot prevent the living from dying, but he can ensure that what was best about them lives on.

In his characteristically insightful discussion of the opening lines of Nemean 6, Michael Theunissen contemplates both interpretations of the

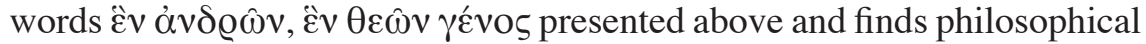
arguments that would make sense of each. However, I am pleased to note that in the end he comes down in favour of the "unity" thesis (pp. 233-234). Interestingly, he compares Pindar's view of men and gods with the negative picture given by Semonides (fr. 1 West) of human existence: vov̂ऽ $\delta$ ' oủx

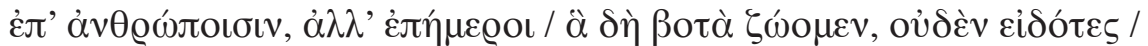

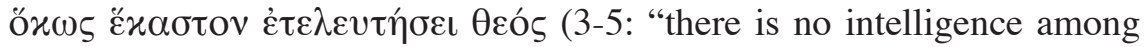
men, but we live like grazing animals, subject to what the day brings, with no knowledge of how the god will bring each thing to pass"). Theunissen thinks there is a possible reminiscence of Semonides' words at the beginning of Nemean 6 - again, the idea that Pindar is refuting an earlier poet is inescapable; certainly, as mortals we will prefer Pindar's view that we are more like gods than Semonides' that we are more like animals. The verbal parallels are certainly striking.

More striking, however, is how Pindar uses the language of Homeric, Hesiodic and perhaps Semonidean tradition to follow an original path all of his own, uniquely evoking inherited ideas with a view to refuting them: Semonides had said humans have no vov̂s, Xenophanes that our vó $\mu \alpha$ is not divine, but Pindar says that we do have a $\mu \dot{\varepsilon} \gamma \alpha \varsigma$ vóos which is practically divine. And he says so in terms so thought-provoking and lastingly ambiguous that even today we are still amazed and delighted by their power to provoke discussion. "Poet-thinker" indeed.

\section{BIBLIOGRAPHY}

Bowra, C.M. 1964, Pindar, Oxford.

Bundy, E. 1986, Studia Pindarica, Berkeley.

Burnett, A.P. 2005, Pindar's Songs for Young Athletes of Aigina, Oxford. Burton, R.W.B. 1962, Pindar's Pythian Odes: Essays in Interpretation, Oxford.

Currie, B. 2005, Pindar and the Cult of Heroes, Oxford.

Dawe, R.D. (1993), The Odyssey: Translation and Analysis, Lewes.

FARNell, L.R. 1965, Pindar: A Commentary, Amsterdam. 
FRÄNKEL, H. 1962, Dichtung und Philosophie des frühen Griechentums, München.

Gerber, D. 1999, "Pindar, Nemean Six: a Commentary", HSCP 99, 33-91. Hollingdale, R. J. 2001², Nietzsche: The Man and his Philosophy, Cambridge.

JAEGER, W. 1934, Paideia, Berlin.

JANKe, W. 2005, Archaischer Gesang: Pindar, Hölderlin, Rilke, Werke und Wahrheit, Würzburg.

Jurenka, H. 1899, "Pindars sechtes nemeisches Siegeslied", Philologus 58, 348-361.

Kloch-Konnitz, P 1961, "Zum Anfang von Pindars Nemea VI” Hermes 89, 370-371.

Lourenço, F. (org.) 2006, Ensaios sobre Píndaro, Lisboa.

- (2009), "Lírica Coral e Monódica: uma problemática revisitada", Humanitas 61, 19-29.

MaeHLER, H. 1963,Die Auffassung des Dichterberufs imfrühen Griechentum bis zur Zeit Pindars, Göttingen.

Norwood, G. 1945, Pindar, Berkeley.

RACE, W.H. 2004, "Pindar's Olympian 11 revisited post-Bundy", HSCP 102, 69-96.

Rose, P.W. 1992, Sons of the Gods, Children of the Earth: Ideology and Literary Form in Ancient Greece, Ithaca (N.Y.).

Sullivan, S.D. 1990, "An Analysis of the psychic term vóos in Pindar and Bacchylides", Glotta 68, 179-202.

Theunissen, M. 2000, Pindar: Menschenlos und Wende der Zeit, München.

Wilamowitz-MoellendorfF, U. von 1922, Pindar, Berlin. 